\title{
PENGUJIAN BEBERAPA KONSENTRASI CUKA KAYU TERHADAP PERTUMBUHAN DAN HASIL TANAMAN KACANG EDAMAME (Glycine max (L) Merill)
}

\author{
Oleh : \\ Ramli*) \\ Widya Sari*) \\ Ina Nuryanah**)
}

\begin{abstract}
Abstrak
Kedelai edamame atau kedelai sayur termasuk spesies (Glycine max (L). Merill) ini merupakan jenis bahan makanan yang populer sebagai makanan ringan maupun bahan campuran makanan. Cuka kayu dapat berfungsi untuk mempercepat pertumbuhan tanaman, inhibitor (pencegah hama dan penyakit). Tujuan dari penelitian ini adalah untuk mengetahui apakah konsentrasi cuka kayu berpengaruh terhadap pertumbuhan dan hasil tanaman kacang edamame. Penelitian ini dilaksanakan pada bulan Februari hingga Maret 2020. Kegiatan penelitian ini dilaksanakan di kebun percobaan di Kp. Longkewang Desa Gasol Cugenang Cianjur. Rancangan percobaan yang digunakan dalam penelitian ini adalah (RAL) dengan 6 perlakuan 3 ulangan pada setiap perlakuan terdiri dari 4 unit sehingga dihasilkan 72 unit percobaan. Hasil pengolahan data secara statistik menyatakan bahwa pemberian konsentrasi $(\mathrm{T} 5)=5 \mathrm{ml} / 1 \mathrm{~L}$ air berpengaruh terhadap parameter pertumbuhan tanaman Edamame, dengan rata-rata tinggi tanaman paling baik $50,10 \mathrm{~cm}$, warna daun 5,00 , jumlah bunga 18,25 , jumlah bintil akar 18,25 biji dan berat buah 15,55 gr. Akan tetapi konsentrasi cuka kayu tidak berpengaruh beda nyata terhadap jumlah daun tanam edamame
\end{abstract}

Kata kunci: Cuka kayu, Edamame, Hama dan Penyakit, Hasil, Inhibitor, Pertumbuhan.

\begin{abstract}
Edamame is Glycine max (L). Merill species. It is popular as a snack or food mixture. Wood vinegar can function for inbibitor, can used to accelerate the growth of plants, and used as inbibitors (preventing pests and diseases). The purpose of this study find was out to fit concentration of wood vinegar effect on growth and result edamame beans. The experimental the design used in this study was completely randomized design (CRD) with 6 treatments and 3 replications. Each treatment consisting of 4 units to produce 72 experimental units. This research was conducted in February to March 2020. The research activity was carried out in the experimental garden in Longkewang, Gasol village Cugenang Cianjur. From the analysis, it was concluded that (T5) concentrantion $(5 \mathrm{~mL} / \mathrm{L})$ affected the Edamame plant parameters. I'e plant height, leaf color, number of flowers, number of root nodules and fruit weight. But it did not affect the number of leaves. (T5) treatment or $=5 \mathrm{~mL} / \mathrm{L}$ water was a treatment that gave the effect of Edamame plant growth, with an average plant height of $50.10 \mathrm{~cm}$, leaf color 5.00 , number of flowers 18.25 , number of root nodules 18, 25 seeds and fruit weight $15.55 \mathrm{gr}$.
\end{abstract}

Keywords: Edamame (Glycine max (L). Merill), growth, Inbibitor, pests and diseases, Wood vinegar.

*) Dosen Fakultas Sains Terapan UNSUR.

**) Alumni Fakultas Sains Terapan UNSUR.

PENGUJIAN BEBERAPA KONSENTRASI

RAMLI, WIDYA SARI dan INA NURYANAH

CUKA KAYU TERHADAP PERTUMBUHAN

DAN HASIL TANAMAN KACANG

EDAMAME (Glycine max (L) Merill) 


\section{PENDAHULUAN}

Edamame merupakan tanaman tropis yang berasal dari Negara Jepang dan termasuk dalam kategori sayuran (green soybean vegetable) juga mengandung sedikit pati penghasil gas. Kedelai dengan kultivar ini masih terbilang sedikit dibudidayakan di Indonesia. Kedelai edamame mengandung kadar gizi yang cukup tinggi yaitu 582 kkal 100 g-1, protein 11,4 g $100 \mathrm{~g}-1$, karbohidrat 7,4 g $100 \mathrm{~g}-1$, lemak 6,6 g $100 \mathrm{~g}-1$ vitamin A $100 \mathrm{mg} 100 \mathrm{~g}-1$, B1 0,27 mg $100 \mathrm{~g}-1$, B2 0,14 mg $100 \mathrm{~g}-1$, B3 $1 \mathrm{mg} 100 \mathrm{~g}-1$, dan vitamin C $27 \%$, serta mineral-mineral seperti fosfor $140 \mathrm{mg} 100 \mathrm{~g}-1$, kalsium 70 mg $100 \mathrm{~g}-1$, besi $1,7 \mathrm{mg} 100 \mathrm{~g}-1$, dan kalium 140 mg $100 \mathrm{~g}-1$ (Paripurnani et al., 2018). Kedelai menjadi salah satu komoditas penting di Indonesia, namun perkembangan tanaman kedelai selama 10 tahun terakhir mengalami penurunan yang cukup besar yakni lebih dari $50 \%$, baik dalam produksi dan juga luasan arealnya. Permintaan kedelai yang terus meningkat sebesar $7,22 \%$ per tahun, namun tidak diimbangi oleh produksi dalam negeri untuk memenuhi konsumsi rata-rata 8,12 $\mathrm{kg}$ per kapita per tahun. Produktivitas lokal masih sangat rendah yaitu 1,2 ton ha-1 dibandingkan dengan produktivitas kedelai di Amerika Serikat sebagai salah satu negara produsen kedelai terbesar di dunia yang mencapai 3,6 ton ha-1 (Paripurnani et al., 2018).

Limbah tanaman sering kali dibiarkan begitu saja tidak dimanfaatkan misalnya limbah serutan kayu, sering kali hanya di biarkan membusuk atau di bakar, jika digunakan limbah serutan kayu tersebut tentu akan sangat bermanfaat terutama di bidang pertanian, salah satunya diolah menjadi cuka kayu. Cuka kayu atau asap cair merupakan cairan warna kuning kecoklatan atau coklat kehitaman yang diperoleh dari hasil samping pembuatan arang. Cuka kayu yang merupakan produk kimia organik hasil destilat asap cair dari proses pembuatan arang di mana komponen cuka kayu terdiri dari asam asetat, methanol, fenol, asetol, kreosol, furtural, metilguaiakol dan sikloheksana. Komponen kimia di atas berfungsi untuk mempercepat pertumbuhan tanaman, inhibitor (pencegah hama dan penyakit) pupuk alam dan apabila cuka kayu encer disemprotkan pada daun tanaman membuat daun lebih sehat. Cuka kayu mengandung unsur hara makro dan mikro seperti $\mathrm{P}, \mathrm{K}, \mathrm{Na} . \mathrm{Ca}, \mathrm{Mg}, \mathrm{S}, \mathrm{Fe}, \mathrm{Mn}, \mathrm{Cu}$, dan $\mathrm{Zn}$. Hanya unsur $\mathrm{N}$ yang tersedia sangat kecil. Dengan demikian cuka kayu merupakan pupuk cair organik dan bahan tunggal yang lengkap (Komarayati et.,al 2014).

Komarayati (2004) pemberian cuka kayu akan lebih optimal apabila dibantu dengan arang sebagai media tumbuh yang akan menyebabkan pertumbuhan tanaman lebih baik. Karena arang memiliki pori-pori yang mampu menyerap dan menyimpan air serta unsur hara. Arang hayati (Biochar) merupakan hasil pembakaran dari bahan mengandung karbon yang berbentuk padat dan berpori. Penggunaan arang tidak hanya sebagai bahan bakar alternatif, namun secara inovatif dapat diaplikasikan di bidang pertanian atau kehutanan sebagai pembangun kesuburan tanah. Walaupun bukan sebagai pupuk, arang hayati dapat memperbaiki kualitas dan kondisi tanah secara fisik, kimia dan biologi (Gusmailina et al., 2018).

Tujuan dari penelitian ini yaitu untuk Mengetahui apakah konsentrasi cuka kayu berpengaruh terhadap pertumbuhan tinggi tanaman, jumlah daun dan warna daun. Selanjutnya Mengetahui konsentrasi cuka kayu yang berpengaruh terhadap jumlah bunga, berat buah dan jumlah bintil akar.

\section{METODE PENELITIAN}

\section{Waktu dan Tempat}

Penelitian ini dilakukan di Kp. Longkewang Gasol Cugenang Cianjur, penelitian ini akan di lakukan pada awal bulan Februari - Maret 2020. 


\section{Alat dan Bahan}

Peralatan yang akan digunakan dalam penelitian ini antara lain polybag, semprotan, ember, penggaris, buku, pulpen, bagan warna. Bahan yang di gunakan diantaranya benih edamame varietas yang digunakan yaitu varietas SPM-1 varietas dari E054 (hasil seleksi), tanah, sekam mentah, arang hayati dan cuka kayu.

\section{Tahapan Penelitian}

Tahapan utama yang dilakukan adalah pengaplikasian cuka kayu pada tanaman kacang edamame dengan cara di semprotkan.

a. Persiapan media tanam

Media tanam yang akan digunakan untuk penelitian ini yaitu tanah, arang dan sekam mentah yang kemudian ketiga media ini akan dicampurkan hingga semuanya tercampur dengan rata dengan perband0ingan 1:1:1.

b. Penanaman Penanaman

Benih yang sudah kering akan ditanaman dalam polybag yang berukuran $14 \times 30 \mathrm{~cm}$, masing-masing polybag ditanamai benih sebanyak 3 biji dengan berat media sebanyak $3 \mathrm{~kg}$.

b. Pengaplikasian cuka kayu

Cuka kayu di aplikasikan dengan cara di semprotkan, cuka kayu dilarutkan sesuai perlakuan, yang pertama larutan $1 \mathrm{~mL} / 1 \mathrm{~L}$ air, $2 \mathrm{~mL} / 1 \mathrm{~L}$ air, $3 \mathrm{~mL} / 1 \mathrm{~L}$ air, $4 \mathrm{~mL} / 4 \mathrm{~L}$ air, $5 \mathrm{~mL} / 1 \mathrm{~L}$ air dan kontrol (tanpa perlakuan), pengaplikasian pertama di lakukan pada saat umur tanaman sudah 15 hst dengan volume penyemprotan yaitu $200 \mathrm{~mL} / 12$ tanaman (Vegetatif) dan $500 \mathrm{~mL} / 12$ tanaman (Generatif).

c. Penyiraman

Penyiraman dilakukan rutin sebanyak 2 kali dalam sehari yaitu pagi dan sore hari.

d. Pemupukan

Pemupukan dilakukan setalah tanaman berumur 20 hst yaitu pada saat tanaman sudah tumbuh tunas, yang dilakukan sebanyak 1 kali dalam seminggu dan diaplikasikan sampai tanaman berbunga.

\section{Metode Penelitian}

Penelitian ini merupakan penelitian eksperimental yang bertujuan untuk mengetahui bagaimana pengaruh pemberian cuka kayu terhadap pertumbuhan dan hasil tanaman kacang edamame, parameter yang akan diamati dalam penelitian ini yaitu tinggi tanaman, jumlah daun, warna daun, jumlah bunga, jumlah bintil akar dan berat buah. Penelitian ini menggunakan rancangan acak lengkap (RAL) dengan 6 perlakuan yaitu (T6 : sebagai kontrol ) $(\mathrm{T} 1=1 \mathrm{ml})$, $(\mathrm{T} 2=2 \mathrm{ml})$ dan $(\mathrm{T} 3=3 \mathrm{ml}),(\mathrm{T} 4=4 \mathrm{ml})$ dan (T5 $=5 \mathrm{ml})$ masing-masing perlakuan diulang sebanyak 3 kali dengan 6 perlakuan setiap unit perlakuan terdiri dari 4 tanaman, sehingga didapatkan 72 unit percobaan.

\section{Teknik Pengumpulan Data}

Teknik pengumpulan data dilakukan dengan cara melakukan pengamatan secara langsung kepada obyek yang diteliti:

1. Tinggi tanaman : Pengukuran dilakukan menggunakan pernggaris yang di lakukan pada hari ke 15 hst pengukuran dilakukan sebanyak 3 kali sehari.

2. Jumlah daun: Penghitungan dilakukan secara manual dengan menghitung jumlah daun yang sudah tumbuh, penghitungan dilakukan pada hari ke 15 hst dilakukan 3 hari sekali.

3. Warna daun: Pengukuran warna daun dilakukan menggunakan bagan warna daun (BWD) pengukuran dilakukan pada hari ke 15 hst dengan pengmatan 3 hari sekali.

4. Jumlah bunga : Penghitungan dilakukan secara manual dengan cara menghitung bunga yang ada pada tanaman, penghitungan dilakukan pada hari ke 15 hst dengan pengamatan 3 hari sekali.

5. Jumlah bintil akar : Penghitungan dilakukan secara manual, dengan cara menghitung jumlah bintil akar pada tanaman, penghitungan dilakukan pada hari ke 90 hst. 
6. Berat buah : Penghitungan dilakukan dengan cara ditimbang, timbangan yang digunakan yaitu timbangan digital, penghitungan dilakukan pada saat panen yaitu pada hari ke 90 hst.

\section{Analisis Data dan Pengujian Hipotesis}

Data yang di dapatkan dari hasil pengamatan akan dianalisis menggunakan bantuan komputer di Software Microsoft Excel dan Minitab. Kemudian setelah data diolah menggunakan software tersebut selanjutnya data dianalisis melalui tabel
ANOVA / tabel sidik ragam dengan pengujian beda nyata perlakuan menggunakan Uji Tukey pada Alpha 5\%.

\section{HASIL DAN PEMBAHASAN}

\section{Tinggi Tanaman}

Pengamatan dilakukan tiga kali sehari sampai tanaman berumur 90 hari, hasil analisis data menggunakan ANOVA dan uji tukey 5\%. Mulai minggu pertama sampau ke lima menunjukkan pengaruh berbeda nyata.

Tabel 1. Rata - rata tinggi tanaman edamame (cm) pengukuran 1-5 dengan berbagai konsentrasi cuka kayu.

\begin{tabular}{cllccccc}
\hline \multirow{2}{*}{ Perlakuan } & \multicolumn{7}{c}{ Pengamatan ke- } \\
\cline { 2 - 7 } & \multicolumn{2}{c}{$\mathbf{1}$} & $\mathbf{2}$ & $\mathbf{3}$ & $\mathbf{4}$ & $\mathbf{5}$ \\
\hline T1 & $10,90 \mathrm{ab}$ & 22,15 & $\mathrm{c}$ & $26,07 \mathrm{ab}$ & $31,25 \mathrm{~b}$ & $41,88 \mathrm{~b}$ \\
T2 & $11,87 \mathrm{ab}$ & $23,75 \mathrm{abc}$ & $27,00 \mathrm{ab}$ & $35,95 \mathrm{ab}$ & $48,00 \mathrm{ab}$ \\
T3 & $12,05 \mathrm{ab}$ & $22,52 \mathrm{bc}$ & $25,32 \mathrm{~b}$ & $34,27 \mathrm{ab}$ & $45,00 \mathrm{ab}$ \\
T4 & $10,07 \mathrm{~b}$ & 21,97 & $\mathrm{c}$ & $25,30 \mathrm{~b}$ & $34,17 \mathrm{ab}$ & $43,27 \mathrm{ab}$ \\
T5 & $14,32 \mathrm{a}$ & $24,90 \mathrm{ab}$ & $28,50 \mathrm{a}$ & $41,88 \mathrm{a}$ & $50,10 \mathrm{a}$ \\
T6 & $13,25 \mathrm{ab}$ & $25,72 \mathrm{a}$ & $28,22 \mathrm{ab}$ & $33,50 \mathrm{~b}$ & $41,32 \mathrm{~b}$ \\
\hline
\end{tabular}

Keterangan: Angka yang diikuti dengan huruf yang sama pada kolom yang sama tidak berbeda nyata pada taraf 5\% uji tukey. Perlakuan T1 (1ml/L), T2 (2ml/L), T3 $(3 \mathrm{ml} / \mathrm{L})$, T4 (4 ml/L), T5 (5 ml/L), T6 (kontrol tanpa perlakuan).

Pengamatan pertama, pemberian cuka kayu konsentrasi T5 memberikan pengaruh yang berbeda nyata dengan perlakuan $\mathrm{T} 4$, namun berbeda tidak nyata dengan T1, T2, T3 dan T6 (kontrol). Pada pengamatan kedua perlakuan T5, T2, T3 dan T6 tidak memberikan pengaruh yang berbeda nyata tetapi pada perlakuan T4 dan T1 memberikan pengaruh yang berbeda nyata terhadap perlakuan yang lainnya. Selanjutnya pengamatan ketiga pada perlakuan T5 memberikan pengaruh berbeda nyata terhadap T3 dan T4 tetapi T5 tidak memberikan perngaruh berbeda nyata terhadap T1, T2 dan T6. Pada pengamatan ke empat dan kelima T5 memberikan pengaruh berbeda nyata dengan T1 dan T6 tetapi T5 tidak berbeda nyata dengan pemberian T2, T3 dan T4.

Pemberian cuka kayu pula mampu lebih optimal dibantu dengan arang sebagai media tumbuh yang menyebabkan pertumbuhan tanaman lebih baik dikarenakan memiliki pori-pori yang menyerap dan menyimpan air serta unsur hara (Komarayati et al., 2014).

\section{Jumlah Daun}

Pengamatan dilakukan tiga kali sehari sampai tanaman berumur 90 hari, hasil analisis data menggunakan ANOVA dan uji tukey 5\%. Mulai minggu pertama sampai ke lima menunjukkan pengaruh berbeda nyata. 
Tabel 2. Rata- rata jumlah daun tanaman edamame penghitungan 1-5 dengan berbagai konsentrasi cuka kayu.

\begin{tabular}{cccccc}
\hline \multirow{2}{*}{ Perlakuan } & \multicolumn{5}{c}{ Penghitungan ke } \\
\cline { 2 - 6 } & $\mathbf{1}$ & $\mathbf{2}$ & $\mathbf{3}$ & $\mathbf{4}$ & $\mathbf{5}$ \\
\hline T1 & $3,50 \mathrm{a}$ & $8,75 \mathrm{a}$ & $13,75 \mathrm{a}$ & $23,00 \mathrm{a}$ & $27,50 \mathrm{a}$ \\
T2 & $4,00 \mathrm{a}$ & $8,75 \mathrm{a}$ & $14,50 \mathrm{a}$ & $24,50 \mathrm{a}$ & $29,00 \mathrm{a}$ \\
T3 & $4,00 \mathrm{a}$ & $8,75 \mathrm{a}$ & $13,25 \mathrm{a}$ & $22,50 \mathrm{a}$ & $26,50 \mathrm{a}$ \\
T4 & $4,00 \mathrm{a}$ & $9,50 \mathrm{a}$ & $13,25 \mathrm{a}$ & $21,75 \mathrm{a}$ & $27,75 \mathrm{a}$ \\
T5 & $3,75 \mathrm{a}$ & $9,75 \mathrm{a}$ & $13,50 \mathrm{a}$ & $23,50 \mathrm{a}$ & $28,50 \mathrm{a}$ \\
T6 & $3,25 \mathrm{a}$ & $10,2 \mathrm{a}$ & $13,75 \mathrm{a}$ & $20,00 \mathrm{a}$ & $24,75 \mathrm{a}$ \\
\hline
\end{tabular}

Keterangan: Angka yang diikuti dengan huruf yang sama pada kolom yang sama tidak berbeda nyata pada taraf 5\% uji tukey. Perlakuan T1 (1ml/L), T2 ( $2 \mathrm{ml} / \mathrm{L})$, T3 $(3 \mathrm{ml} / \mathrm{L})$, T4 (4 ml/L), T5 (5 ml/L), T6 (kontrol tanpa perlakuan).

Berdasarkan pengamatan jumlah daun tanaman Edamame pada minggu pertama, kedua, ketiga, keempat dan kelima menunjukan pengaruh yang tidak berbeda nyata.. Hal ini diduga cuka kayu tidak mampu menstimulasi pertumbuhan jumlah daun dan hanya dipengaruhi oleh unsur hara yang ada pada tanah dari pengaplikasian pupuk. Pupuk terdiri dari pupuk organik dan pupuk anorganik. Pupuk organik memiliki peranan untuk menggemburkan lapisan tanah, meningkatkan daya simpan air, dan meningkatkan kesuburan tanah. Pupuk anorganik memiliki unsur yang mencukupi kebutuhan tanaman dalam jumlah yang besar (Mulyani 2002 dalam Hamdani et al., 2013).

\section{Warna Daun}

Pengamatan dilakukan tiga kali sehari sampai tanaman berumur 90 hari, hasil analisis data menggunakan ANOVA dan uji tukey 5\%. Mulai minggu pertama sampai ke lima menunjukkan pengaruh berbeda

Tabel 3. Rata-rata warna daun tanaman edamame pada pengukuran 1-5 dengan berbagai konsentrasi cuka kayu.

\begin{tabular}{ccccccc}
\hline \multirow{2}{*}{ Perlakuan } & $\mathbf{7}$ & Pengukuran ke & $\mathbf{4}$ & $\mathbf{5}$ \\
\cline { 2 - 6 } & $\mathbf{1}$ & $\mathbf{2}$ & $\mathbf{3}$ & $4,50 \mathrm{a}$ & $4,00 \mathrm{~b}$ \\
T1 & $3,50 \mathrm{a}$ & $4,50 \mathrm{ab}$ & $4,25 \mathrm{ab}$ & $4,50 \mathrm{a}$ & $4,50 \mathrm{ab}$ \\
T2 & $3,75 \mathrm{a}$ & $4,75 \mathrm{a}$ & $4,25 \mathrm{ab}$ & $4,25 \mathrm{a}$ & $4,25 \mathrm{ab}$ \\
T3 & $4,00 \mathrm{a}$ & $4,00 \mathrm{~b}$ & $4,00 \mathrm{~b}$ & $4,25 \mathrm{a}$ & $4,25 \mathrm{ab}$ \\
T4 & $3,75 \mathrm{a}$ & $4,00 \mathrm{~b}$ & $4,25 \mathrm{ab}$ & $4,50 \mathrm{a}$ & $5,00 \mathrm{a}$ \\
T5 & $3,50 \mathrm{a}$ & $4,00 \mathrm{~b}$ & $5,00 \mathrm{a}$ & $4,50 \mathrm{a}$ & $4,00 \mathrm{~b}$ \\
T6 & $3,50 \mathrm{a}$ & $4,00 \mathrm{~b}$ & $4,50 \mathrm{ab}$ & $\mathrm{b}$
\end{tabular}

Keterangan: Angka yang diikuti dengan huruf yang sama pada kolom yang sama tidak berbeda nyata pada taraf 5\% uji tukey. Perlakuan T1 (1ml/L), T2 ( $2 \mathrm{ml} / \mathrm{L})$, T3 $(3 \mathrm{ml} / \mathrm{L})$, T4 (4 ml/L), T5 (5 ml/L), T6 (kontrol tanpa perlakuan).

Berdasarkan warna daun tanaman Edamame menunjukkan adanya pengaruh dari pemberian cuka kayu, pada pengukuran pertama dan keempat pengaruh cuka kayu tidak berbeda nyata dengan dosis yang lainnya, pada pengukuran kedua pemberian dosis $\mathrm{T} 2$ berbeda nyata dengan T3, T4, T5 dan T6 tetapi tidak berbeda nyata dengan $\mathrm{T} 2$ dan T1. Pengukuran ketiga pemberian dosis T5 memberikan pengaruh tidak nyata pada T1, T2, T4 dan T6 tetapi T5 berbeda nyata dengan pemberian dosis T3. Pada pengukuran kelima T5 memberikan pengaruh tidak berbeda nyata dengan $\mathrm{T} 2$, T3 dan T 4 namun T5 berbeda nyata dengan T1 dan T6.

Pembentukan warna daun pada tanaman Edamame di duga disebabkan oleh kandungan $\mathrm{N}$ pada cuka kayu ataupun kandungan yang di sebabkan oleh bakteri pengikat $\mathrm{N}$ yaitu Bakteri Rbizobium. Nitrogen $(\mathrm{N})$ merupakan unsur hara yang sangat dibutuhkan oleh tanaman dalam jumlah yang besar. Nitrogen merupakan anasir penting dalam 
pembentukan klorofil. Unsur ini mempunyai peranan yang penting dalam pertumbuhan dan perkembangan semua jaringan hidup (Brady dan Weil, 2002). Unsur hara $\mathrm{N}$ menjadi unsur hara utama penyusun Klorofil, yang memiliki peranan penting dalam proses fotosintesis pada tanaman. Tanaman yang kekurangan unsur hara $\mathrm{N}$, daunnya akan menguning sehingga proses fotosintetis tidak maksimal. (Wahid, 2003).

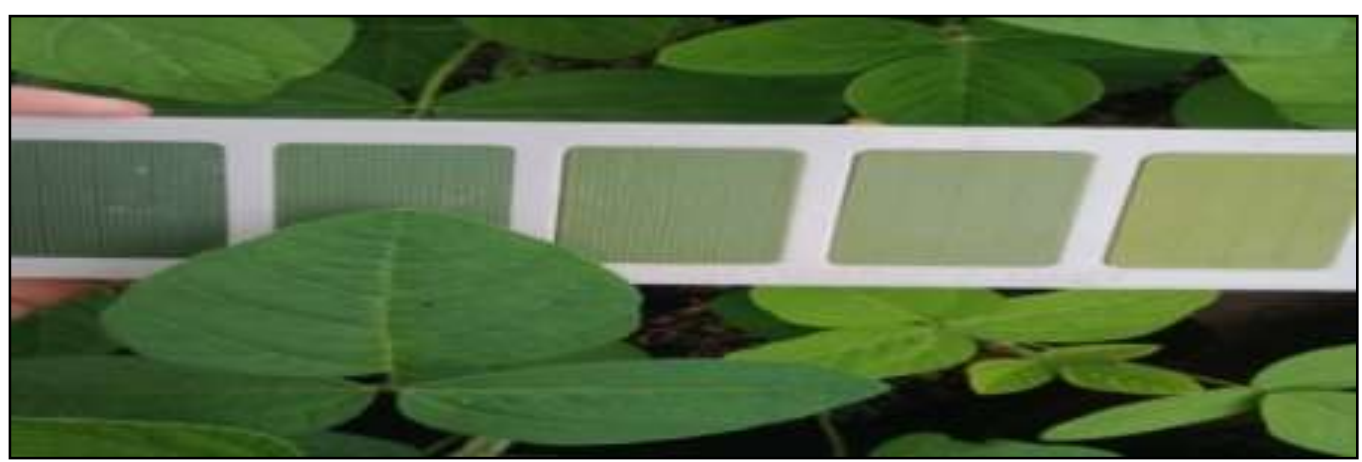

Gambar 1. Pengukuran warna daun.

\section{Jumlah Bunga}

Pengamatan dilakukan sebanyak tiga kali sampai tanaman akan mencapai umur 90 hari, hasil analisis data menggunakan ANOVA dan uji tukey 5\%. Mulai minggu pertama sampai ke lima menunjukkan pengaruh berbeda nyata.

Tabel 4. Jumlah bunga tanaman edamame penghitungan pada minggu 8-10 dengan berbagai konsentrasi cuka kayu.

\begin{tabular}{cccc}
\hline \multirow{2}{*}{ Perlakuan } & \multicolumn{3}{c}{ Jumlah/ming } \\
\cline { 2 - 4 } & $\mathbf{8}$ & $\mathbf{9}$ & $\mathbf{1 0}$ \\
\hline T1 & $4,75 \mathrm{a}$ & $11,25 \mathrm{ab}$ & $14,25 \mathrm{ab}$ \\
T2 & $4,50 \mathrm{a}$ & $12,00 \mathrm{ab}$ & $12,75 \mathrm{~b}$ \\
T3 & $4,50 \mathrm{a}$ & $12,50 \mathrm{ab}$ & $14,50 \mathrm{ab}$ \\
T4 & $5,00 \mathrm{a}$ & $13,50 \mathrm{ab}$ & $16,50 \mathrm{ab}$ \\
T5 & $5,50 \mathrm{a}$ & $14,75 \mathrm{a}$ & $18,25 \mathrm{a}$ \\
T6 & $4,25 \mathrm{a}$ & $10,00 \mathrm{~b}$ & $11,75 \mathrm{~b}$ \\
\hline
\end{tabular}

Keterangan: Angka yang diikuti dengan huruf yang sama pada kolom yang sama tidak berbeda nyata pada taraf 5\% uji tukey. Perlakuan T1 (1ml/L), T2 ( $2 \mathrm{ml} / \mathrm{L})$, T3 (3 ml/L), T4 (4 ml/L), T5 (5 ml/L), T6 (kontrol tanpa perlakuan).

Berdasarkan jumlah bunga tanaman edamame memberikan adanya pengaruh dari pemberian konsentrasi cuka kayu, pada pengukuran pertama pada minggu ke delapan pemberian konsentrasi cuka kayu memberikan pengaruh tidak berbeda nyata pada setiap dosisnya, di lanjutkan dengan pengukuran ke dua T5 memberikan pengaruhu berbeda nyata terhadap T6 namun tidak berbeda nyata dengan T1, T2, T3 dan T4. Yang terakhir pengukuran ketiga yaitu konsentrasi T5 menunjukkan pengaruh berbeda nyata terhadap T2 dan T6 tetapi tidak berbeda nyata dengan T1, T3 dan T4.
Menurut Jumin (2005) pada masa vegetatif tanaman akan sangat di pengaruhi oleh adanya kandungan unsur hara yang baik, jika unsur hara yang diberikan cukup bagi tanaman maka hasilnya akan baik. Unsur hara $\mathrm{N}$ berperan dalam penyusun asam-asam amino, protein serta bahan penyusun komponen inti sel, Pemberian pupuk N yang berlebihan dapat meningkatkan kerusakan akibat serangan hama dan penyakit terutama pada musim hujan, (Wahid, 2003). 


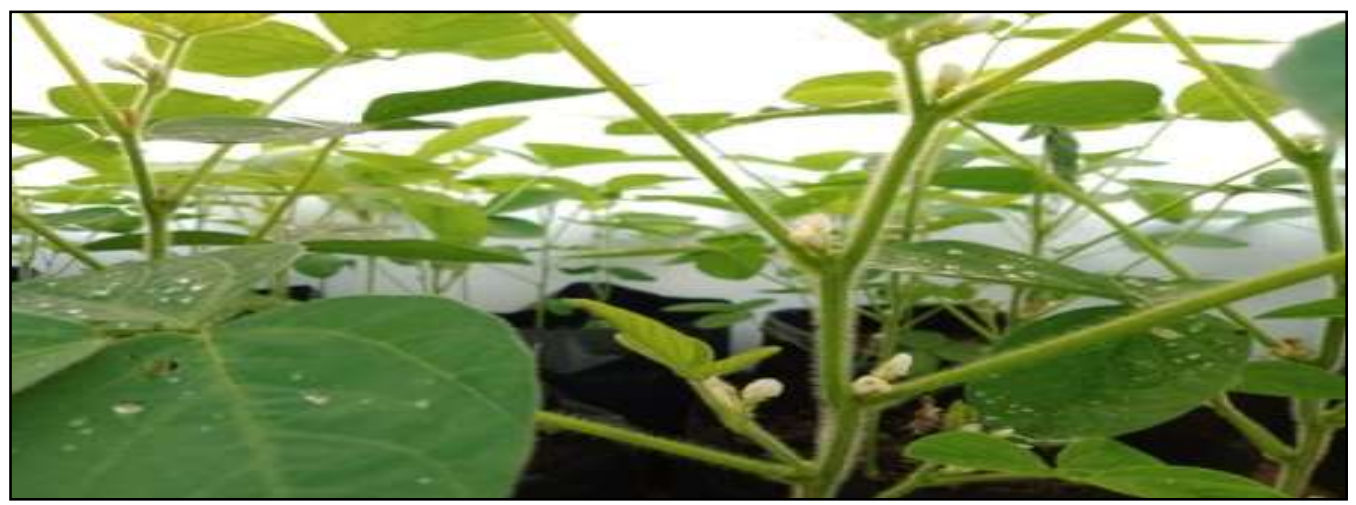

Gambar 2. Penghitungan jumlah bunga.

\section{Jumlah Bintil Akar}

Penghitungan jumlah bintil akar dilakukan sebanyak 1 kali dan dilakukan pada saat umur 90 hari/panen. Hasil analisis data menggunakan ANOVA dan uji tukey $5 \%$, tabel di atas menunjukkan pengaruh berbeda nyata.

Tabel 5. Rata-rata jumlah bintil akar tanaman edamame dengan berbagai konsentrasi cuka kayu.

\begin{tabular}{cc}
\hline Perlakuan & Rata-rata jumlah bintil akar \\
\hline T1 & $16,75 \mathrm{ab}$ \\
T2 & $14,00 \mathrm{ab}$ \\
T3 & $14,50 \mathrm{ab}$ \\
T4 & $14,00 \mathrm{ab}$ \\
T5 & $18,25 \mathrm{a}$ \\
T6 & $6,25 \mathrm{~b}$ \\
\hline
\end{tabular}

Keterangan: Angka yang diikuti dengan huruf yang sama pada kolom yang sama tidak berbeda nyata pada taraf 5\% uji tukey. Perlakuan T1 (1ml/L), T2 ( $2 \mathrm{ml} / \mathrm{L})$, T3 $(3 \mathrm{ml} / \mathrm{L})$, T4 $(4 \mathrm{ml} / \mathrm{L})$, T5 (5 ml/L), T6 (kontrol tanpa perlakuan).

Berdasarkan penghitungan bintil akar, tanaman Edaname memberikan pengaruh terhadap pemberian cuka kayu pada penghitungan pertama pengaruh cuka kayu pada konsentrasi T5 memberikan pengaruh berbeda nyata terhadap T6 namun T5 tidak bebrebda nyata dengan T1, T2, T3 dan T4.

Cuka kayu berpengaruh terhadap sifat fisik, kimia, dan biologi tanah. Pemberian bahan organik memperbaiki sifat fisik tanah dan tidak meninggalkan residu pada tanaman (Ismawati 2003 dalam Ariesta 2013). Struktur menjadi remah sehingga memungkinkan pertumbuhan akar lebih cepat. Hal ini di dukung oleh Komarayati et al., (2014) Bila kualitas tanah baik maka pertumbuhan organisme dalam tanah akan meningkat, salah satunya adalah bakteri Rhizobium. Rbizobium merupakan kelompok bakteri berkemampuan sebagai penyediahara bagi tanaman kedelai, karena potensinya dapat bersimbiosis mutualisme dengan tanaman polong (Leguminoceae) dengan cara membentuk bintil pada akar tanaman polong. Bintil akar berfungsi mengambil nitrogen diatmosfer dan menyalurkannya sebagai unsur hara yang diperlukan tanaman inang. Rhizobium mampu menyumbangkan $\mathrm{N}$ dalam bentuk asam amino yang merupakan unsur paling penting bagi pertumbuhan tanaman kedelai (Soedarjo, 2003).

\section{Berat Buah}

Penghitungan berat buah dilakukan sebanyak 1 kali dan dilakukan pada saat umur 90 hari/panen. Hasil analisis data menggunakan ANOVA dan uji tukey 5\%, tabel di atas menunjukkan pengaruh berbeda nyata. 
Tabel 6. Rata-rata berat Buah tanaman edamame dengan berbagai konsentrasi cuka kayu.

\begin{tabular}{cc}
\hline Perlakuan & Berat buah/gram \\
\hline T1 & $15,41 \mathrm{a}$ \\
T2 & $15,78 \mathrm{a}$ \\
T3 & $13,51 \mathrm{a}$ \\
T4 & $13,70 \mathrm{a}$ \\
T5 & $15,55 \mathrm{a}$ \\
T6 & $7,56 \quad \mathrm{~b}$ \\
\hline
\end{tabular}

Keterangan: Angka yang diikuti dengan huruf yang sama pada kolom yang sama tidak berbeda nyata pada taraf 5\% uji tukey. Perlakuan T1 (1ml/L), T2 ( $2 \mathrm{ml} / \mathrm{L})$, T3 $(3 \mathrm{ml} / \mathrm{L}), \mathrm{T} 4(4 \mathrm{ml} / \mathrm{L})$, T5 (5 ml/L), T6 (kontrol tanpa perlakuan).

Berdasarkan penghitungan berat buah tanaman Edaname memberikan pengaruh terhadap pemberian cuka kayu, pada pemberian konsentrasi T6 memberikan pengaruh berbeda nyata terhadap dosis lainnya yaitu T1, T2, T3, T4 dan T5. Menurut Jumin (2005) pada masa vegetatif tanaman akan sangat di pengaruhi oleh adanya kandungan unsur hara yang baik. Selanjutnya Lamptey et al., (2003), pada fase pertumbuhan generatif, tanaman kedelai sangat memerlukan unsur

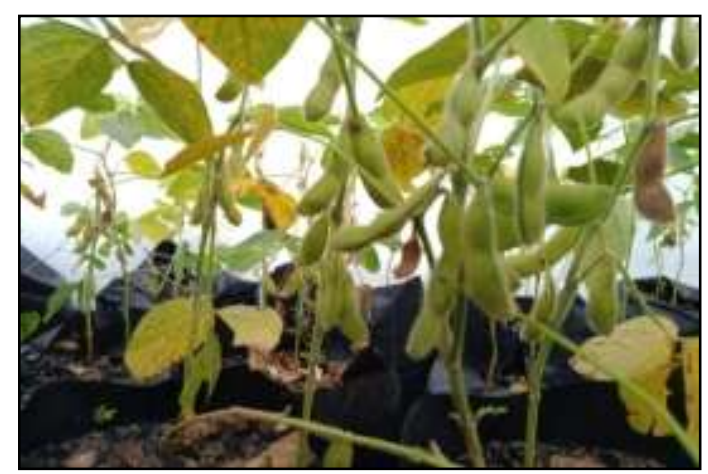

Gambar 3. Buah Edamame.

\section{KESIMPULAN}

Berdasarkan hasil penelitian dapat disimpulkan bahwa pemberian konsentrasi $(\mathrm{T} 5)=5 \mathrm{ml} / 1 \mathrm{~L}$ air berpengaruh terhadap parameter pertumbuhan tanaman Edamame, dengan rata-rata tinggi tanaman paling baik 50,10 $\mathrm{cm}$, warna daun 5,00, jumlah bunga 18,25, jumlah bintil akar 18,25 biji dan berat buah 15,55 gr, akan tetapi konsentrasi cuka kayu tidak berpengaruh beda nyata terhadap jumlah daun tanaman edamame. nitrogen untuk pembentukkan protein pada biji kedelai. Menurut Purwaningsih et al.(2012) tanaman kedelai menyerap 70-80 $\mathrm{g}$ nitrogen untuk menghasilkan $1 \mathrm{~kg}$ biji. Tersedianya nitrogen dalam tanah bisa berasal dari pupuk maupun dari hasil fiksasi nitrogen bebas oleh bakteri. Bakteri yang bisa memfiksasi nitrogen bebas ialah bakteri Rhizobium. Bakteri Rhizobium dapat bersimbiosis akar tanaman legum salah satunya jenis kedelai edamame.

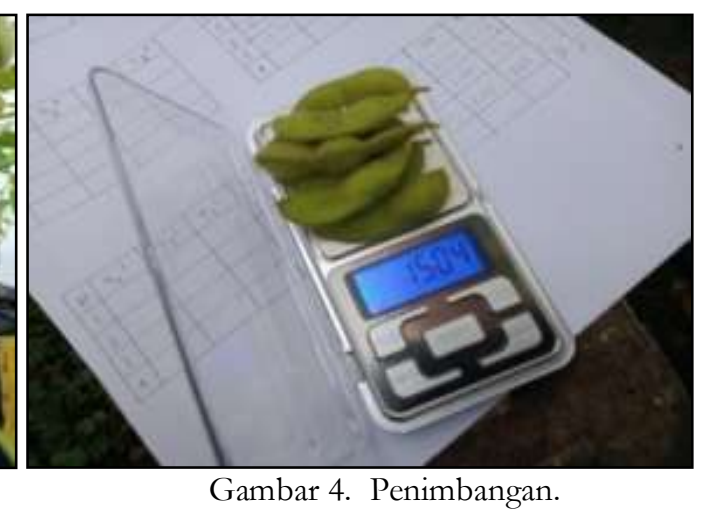

DAFTAR PUSTAKA
Ariesta, M. 2013. Pengaruh Aplikasi Cuka Kayu Terhadap Hama Dan Pertumbuhan Tanaman Tomat dengan Sistem Budidaya Organik. skripsi. Program Studi Agroteknologi Universitas Sebelas Maret. Surakarta.

Brady NC and RR Weil. 2002, The Nature and Properties of Soils. Edition. Upper Saddle River, New Jersey. US A. G.

Gusmailina, G., Komarayati, S., \& Wibisono, H. S. 2018. Pengaruh Arang Dan Asap Cair Terhadap Pertumbuhan Anakan Gyrinops sp. Jurnal Penelitian Hasil Hutan. 36 (1): 
23-31.

Jumin. H.B., 2005. Ekologi Tanaman Suatu Pendekatan Fisiologis. Rajawali Press. Jakarta.

Komarayati, S., \& Pari, G. 2014. Kombinasi Pemberian Arang Hayati Dan Cuka Kayu Terhadap Pertumbuhan Jabon Dan Sengon. Jurnal Penelitian Hasil Hutan. 32 (1) : 12-20.

Lamptey, S., Ahiabor, B. D. K., Yeboah, S., and Osei, D. 2014 Effect of Rhizobium Inoculants and Reproductive Growth Stages on shoot Biomass and Yield of Soybean (Glycine max (L) Merril). Journal of Agricultural science. 6(5):44.

Hamdani, A., Rahmat, B., \& Zumani, D. 2013. Efikasi Konsentrasi Cuka Kayu Terhadap Pertumbuhan Tanaman Kedelai (Glycine max (L) Merri) dan Pengendalian Penyakit Layu Pucuk. Journal of Chemical Information and Modeling.

Paripurnani, S., Dibia, I., \& Atmaja, I. W.
D. 2018. Pengaruh Pupuk Organik dan Anorganik Terhadap Peningkatan Produksi Edamame (Glycine max (L) Merill) Pada Tanah Subgroup Vertik Epiaquepts di Pegok, Denpasar. E-jurnal Agroteknologi Tropika. 7 (1):141-153.

Purwaningsih, O,. Indradewa, D., Kabirun, S., Shiddiq. 2012. Tanggapan Tanaman Kedelai Terhadap Inokulasi Rhizobium. Jurnal Agrotop. 2(1) : 25-32.

Soedarjo, Muchdar. Nasir, Saleh. Adisarwanto, Titis. Modar, Darman. Manshuri, A. Ghozi and Ishiki, Koshun 2003. Caracterization and Effectiveness of Acid-Tolerant Rhizobia Isolated From Nodules of Soybean Cultivated in Indonesia. Japanese Journal Of Tropical Agriculture. 47(4).

Wahid, A.S., 2003. Peningkatan Efisiensi Pupuk Nitrogen Pada Padi Sawah Dengan Metode Bagan Warna Daun. Jurnal Libang Pertanian. 